\title{
Mýtus o demokracii a revolúcii
}

\author{
Ladislav Hohoš
}

HOHOŠ, L.: The Myth of Democracy and of Revolution

Philosophica Critica, vol. 7, 2021, no. 2, ISSN 1339-8970, pp. 54-73.

The term democracy is nowadays too often used and eventually abused. This has been the case in the past as well. The ideal of democracy in the modern age is based on the social contract, which is currently failing. The author tried to outline the question of the universalism of democracy in the context of civilization transformation. The controversial link between "democracy" and "capitalism" is still the subject of ideological conflict. Instead of a historical analysis, the author intends to examine the controversial link between "democracy" and "socialism", especially retrospectively in relation to the attempt to implement "democratic socialism“.

Keywords: Democracy - Revolution - Paris Commune - Rule by the proletariat - Social democracy - Democratic socialism

Mezi póly komunismu a neoliberalismu je právě místo pro sociální demokracii: vytvořit demokratický sociální stát. ${ }^{1}$

Poslednou vetou svojej presvedčivej dokumentácie James Krapfl kladie otázku: „Ked' v čase revolúcie nie je čas na demokraciu, kedy je“ (Krapfl $2009,275)$ ? Táto otázka vyjadruje historicky protirečivé osudy konceptov demokracie a revolúcie. Všeobecne prevláda marxistické chápanie, že revolúcia je obrat (prevrat), ktorý zasiahol tak zmeny ekonomické (vlastnícke vztahy, predovšetkým vztahah k výrobným prostriedkom), tak zmeny politické (zmena formy vlády, etablovanie novej vládnúcej triedy). Nedostatkom marxistického výkladu je, že neberie do úvahy kultúru, „kolektívne svedomie“ ktoré udržiava spoločnost' pohromade, symboly a inštitúcie (E. Durkheim). Vzbura proti vlastníckym vztaham sa nestane revolúciou, ak nedôjde k zmene politického režimu; výmena politickej garnitúry bez zmeny vlastníckych vztahov znamená len vystriedanie jednej junty druhou. Prototypom revolúcií sú Francúzska a Ruská revolúcia, boli radikálne a jakobínske, preto krvavé, viedli k etablovaniu novej vládnucej

1 (Hermann 2014, 133) 
triedy v ekonomike i politike. V stredovýchodnej Európe sa skôr potácame od prevratu k prevratu.

\section{Revolúcia alebo prevrat?}

Revolúcia predstavuje proces, ktorý má rôzne fázy, pôvodné radikálne ciele revolucionárov narazia na ducha doby a okolnosti, výsledkom je niečo ako kompromis medzi utópiou a realitou. Historik Miroslav Hroch chápe revolúciu ako trvalú systémovú zmenu. S výhradou, že v dejinách sa vyskytujú rovnako revolúcie úspešné ako aj neúspešné. Ani každá vít’azná revolúcia nebola revolúciou úspešnou, ale ani porážka revolúcie neznamená vždy neúspech cielov. Napríklad revolúcia 1848 v Rakúsko-Uhorskej monarchii bola síce potlačená, ale niektoré revolučné požiadavky ( $\mathrm{v}$ prvom rade zrušenie poddanstva) sa naplnili. Zaradenie ruskej októbrovej revolúcie je podl'a Hrocha zložité. Podla môjho názoru je otázka, či bola revolúciou trvale úspešnou, stále otvorená (Hohoš 2018, 189-215). Hroch vychádza zo skutočnosti, že nedošlo k reštitúcii pomerov cárskeho samoderžavia a prikláňa sa preto k názoru, že ju môžeme zaradit’ medzi revolúcie úspešné (Hroch 2018, 190-192). Pokial' ide o udalosti na konci roku 1989 (atribút revolúcie - „sametová“ podl'a vyznavačov, „textilná“ podla odporcov), James Krapfl prezentuje „obraz prekvapujúco idealistickej revolúcie, ktorá bola zároveň sociálna, politická a do istej miery aj náboženská" (Krapfl 2009, 23). Pritom rozlišuje medzi sociálnou históriou a „novou“ kultúrnou históriou. Podl'a interpretácie kultúry ako „pavučiny významov“ (kultúrny antropológ C. Geerz) Krapflovu tézu akceptujem, podla sociálnej histórie a Hrochovho kritéria ide o reštitutívny prevrat.

Marx chápal revolúciu ako dialektícký skok, pripomína Benjamin, „V čase akcie je revolučným triedam vlastné presvedčenie, že treba rozbit’ kontinuum dejín“ (Benjamin 1999, 233). Či sa tento zámer podarilo naplnit', môže byt' kritériom, či ide o revolúciu alebo prevrat. Uplatnit' uvedené kritérium je však niekedy problematické; podla Benjamina o reinterpretáciu histórie sa permanentne vedie triedny boj. Vo Francúzsku po určitých peripetiách návratu cisárstva definitívne nastúpila republika od roku 1870, kedy musela čelit' prvej vel'kej kríze, ktorá skončila krvavým potlačením Parížskej komúny.

$\mathrm{V}$ česko-slovenských dejinách $\mathrm{v}$ druhej polovici dvadsiateho storočia nastali prevraty tri, z toho doteraz je najkontroverznejší je ten nedokonaný - pokus o tzv. „demokratický socializmus“, pôvodne podla metafory A. Dubčeka „socializmus s l'udskou tvárou“. Predvojnový sociálny demokrat, zaslúžilý funkcionár exilovej SD, sociológ Karel Hrubý († 2021) z tejto pozície reflektuje vývoj politického režimu po prevrate vo februári 1948 
v širšom sociálno-politickom a kultúrno-ideologickom kontexte. Vo svojich polemických textoch prezentuje hlbšie historické súvislosti troch prevratov. $V$ tejto štúdii sa budem podrobnejšie venovat' práve druhému násilne zastavenému prevratu, čo je klúčové aj pre Hrubého. Otázky, čo by bolo, keby, sú v striktnom slova zmysle čisto hypotetické, Hroch ich však pripúšt́a ako čiastočne heuristické. Otázka znie: mal koncept „demokratického socializmu" v ČSSR v roku 1968 alternatívy a poskytuje možnosti do budúcnosti?² Podla Hrubého: „«Demokratický socialismus» «pražského jara» byl ještě před «spojeneckou» invazí teoreticky sám v sobě rozporný a byl v různých segmentech společnosti spojován s nestejnými vývojovými perspektivami“" (Hrubý 2018, 204).

V roku 1968 naplno zaznela naplno požiadavka definitívnej destalinizácie, odklonu od stalinského modelu, liberalizácie a demokratizácie. Hrubý má pravdu, že tieto požiadavky boli značne divergentné napriek proklamovanej zhode komunistov a nekomunistov. Špecifická a pre l'avicu bolestná bola otázka obnovy sociálno-demokratickej strany, čo Dubčekovo vedenie vzhl'adom na vtedajšiu politickú situáciu nepripustilo.

Hlavný prúd, ku ktorému sa priklonila prevažná väčšina spoločnosti, reprezentovali reformní komunisti, generačne mladší a vzdelanejší, dovolávajúci sa leninských metód proti stalinizmu, čo bolo samo osebe rozporné. Pritom nemalú podporu mal tento prúd medzi pracujúcimi vrátane podpory robotníkov a družstevných rol'níkov. Podla vtedajšieho prieskumu verejnej mienky pojanuárové zmeny v roku 196875 \% Čechov a 77 \% Slovákov hodnotilo ako proces, ktorý posilňuje socializmus (Mencl Hájek - Otáhal - Kadlecová 1990, 302). Najvýznamnejším výdobytkom obrodného procesu bolo zavedenie podnikových rád pracujúcich. ${ }^{3}$ Dalším prúdom boli starší súdruhovia, generácia februárového prevratu, ktorí boli zabetónovaní vo funkciách, na ktoré často nestačili a nemali kvalifikáciu. Čast' týchto súdruhov, nielen diskriminovaných v minulých čistkách, ale aj prominentných intelektuálov, konvertovala k obrodnému procesu, niekedy napriek osobnému podielu na stalinských neprávostiach. Ďalšia čast' bud' pasívne vyčkávala alebo sa zaradili medzi tzv. „konzervatívcov“. Pokial' ide o veriacich občanov, mali diferencované postoje vzhl'adom

2 „Alternatíva“ sa vzt’ahuje k niečomu, čo sa stalo alebo sa deje, dajú sa do určitej miery rekonštruovat'. Historická „možnost“" je orientovaná smerom do budúcnosti, otvorenejšia ako možnost' zmeny. Pozri (Hroch 2018, 308-309).

3 Hrubý vyzdvihol, že Šikov model bol výraznou odchýlkou od sovietskeho modelu socializmu a predstavoval odlišný typ socialistickej ekonomiky. „Vcelku se socialismus jakožto sociálno-ekonomický systém během roku 1968 neměnil, plány na jeho reformu, vyšší efektivitu a podílnictví zaměstnanců zůstaly jen v př́ípravném stadiu“ (Hrubý 2018, 204). 
na perzekúcie, prevažne vyčkávali, považovali udalosti za vec komunistov. Segment spoločnosti, nielen seniorov, ale aj nespokojnej mládeže, považovali za normál návrat do pomerov prvej republiky vrátane úplného parlamentného pluralizmu. A boli aj radikálnejšie požiadavky, napríklad na zmenu vojenskej doktríny a dokonca vystúpenie z Varšavskej zmluvy. Smutne známy dokument „Poučenie z krízového vývoja..." identifikoval dve vplyvné antikomunistické zoskupenia, Klub angažovaných nestraníkov a K-231 (nespravodlivo odsúdených). Očakávania, ktoré vyvolával obrodný proces, boli značne diferencované, osobitne by sa bolo treba zmienit' o špecifických požiadavkách Slovenska na štátoprávne usporiadanie, čo sa dramaticky prejavilo po roku 1989. Pokial' by obrodný proces pokračoval, tieto, prípadne d'alšie divergencie by sa prehlbovali.

Hrubého skeptický postoj k reforme zhora (1968) je opodstatnený, pokial' uvažujeme o alternatívach a možnostiach. Alternatívou mohlo byt' zvládnutie obrodného procesu v podobe, aký by bol prijatel'ný pre ZSSR ako v Mad'arsku ${ }^{4}$ alebo odpor voči okupácii s tragickými dôsledkami. Skupina „prestavbárov“ v druhej polovici osemdesiatych rokov vychádzala z osobnej skúsenosti zo svojej mladosti, že reformy socializmu môžu byt' úspešné len s podporou ZSSR. Normalizační komunisti, verní „Poučeniu...” prestavbu nemohli prijat', ocitli sa v pasci vlastnej nehybnosti. M. Gorbačov síce deklaroval reformný program podobný ako svojho času v ČSSR, ale nikdy sa k afinite verejne neprihlásil. Uznával však, že v šest’desiatych rokoch sovietske vedenie premeškalo čas na reformy. Prestavba vyústila do obnovy kapitalizmu v Rusku, mala širšie zámery, ktoré vyplývali z geopolitického postavenia supervel'moci, ktoré nebolo možné v pôvodnom rozsahu ZSSR uhájit'. Podobne v roku 1968 sovietske vojská vyriešili strategický problém umiestnenia vojsk na česko-slovenskom území, čo sa ako dôvod invázie vojsk nedoceňuje.

Ďalej do minulosti, Hrubý tvrdo odsudzuje Benešovo vedenie za orientáciu londýnskeho exilu na ZSSR (Hrubý 2018, 49). Bolo alternatívou prijat’ Marshallov plán ako Fínsko, ktoré sa odvážilo na „statočný odpor“? Hrubý dáva kladnú odpoved'. Teda aj Jan Masaryk bol údajne „nestatočný politik“. Otázne je, či táto alternatíva bola reálna, lebo sovietske vedenie vytváralo svoj blok ako reakciu na rozpad pôvodného spojenectva počas druhej svetovej vojny a dôsledok sformovania sfér vplyvu, čo presahuje rámec tejto štúdie. Pritom prezident Beneš práve podpisom spojeneckej zmluvy so ZSSR dosiahol obnovenie republiky v predvojnových hraniciach

$4 \quad$ So zaujímavou úvahou prišiel L. Štrougal: domnieva sa, že G. Husák bol politikom, ktorý by mal šancu urobit' opatrenia, aby nedošlo v roku 1968 k vojenskej okupácii. Lenže vtedy bol Husák vedením KSS upozadňovaný (Štrougal 2009, 231). 
(s výnimkou Podkarpatskej Rusi). Z uvedeného hypotetického náčrtu vyplýva, že žiadna historická možnost’ realizácie konceptu „demokratického socializmu" nebola, alternatíva v šest'desiatych rokoch bola potlačená a o dvadsat' rokov bolo neskoro. Došlo k inej podstatnej historickej udalosti, zániku bipolárneho sveta studenej vojny a k postupnej premene sveta na makroregióny, ktorých „koncert“ zatial’ bolestne a disharmonicky formuje svetový poriadok (analógia s rokom 1815 alebo rokov 1910, 1930).

Hlavnou námietkou Hrubého voči „demokratickému socializmu“ však je niečo iné, deficit autentickej demokracie, v ktorú veril ako presvedčený sociálny demokrat starej gardy. ${ }^{5}$ Hrubý vnímal síce pozitívne reformy uskutočňované dubčekovským vedením KSČ po januári 1968, hodnotil ich však ako demokratizáciu socializmu, nie „demokratický sociálny štát", ako chápal sociálnodemokratický projekt „demokratického socializmu“. Za závažný politický omyl považoval Hrubý už prijatie komunistických predstáv o politickom usporiadaní na báze Národného frontu po druhej svetovej vojne (Hrubý 2018, 50). Koncept "demokratického socializmu“ v programe nemeckej SD a v rámci Pražskej jari riešil problém sociálnej slobody podla Honnetha iba núdzovo, v snahe nepopierat' hodnotu individuálnych práv a slobôd. Výsledkom bola značne obmedzená myšlienka chápat' politickú demokraciu podla zvyčajného liberálneho vzoru ako inštitucionálnu sféru. Sociálna otázka sa mala v rámci parlamentnej väčšiny riešit' obmedzovaním kapitalistického trhu. Lenže prekonanie kapitalistického privátneho egoizmu z marxistického hladiska predpokladá radikálny postulát - formovanie ekonomickej činnosti tak, aby v nej aktéri mohli byt' činní nie proti sebe, ale pre seba navzájom (Honneth 2020, 67). V tomto smere bol "demokratický socializmus" poznamenaný minulost'ou, kedy socialisti nedokázali v zajatí tradičnej doktríny vymedzit’ normatívny prístup k politickej sfére. Tradičný marxizmus mal pravdu v tom, že dominancia vládnúcej triedy buržoázie v politike trvala až do polovice dvadsiateho storočia, politická sféra sa čiastočne emancipovala až po druhej svetovej vojne s doktrínou l'udských práv.

Návrat k politickej pluralite, či už kontinuitný alebo diskontinuitný, znamenal na konci osemdesiatych rokoch zánik reálneho socializmu. V Pol'sku a v Mad’arsku vládnuce strany postupne uvol'ňovali svoj mocenský monopol, politické režimy sa transformovali prostredníctvom politickej plurality, došlo na dialóg a del'bu moci s opozíciou a vol’by s viacerými kandidátkami. V našej krajine pluralita mimo organizácií Národného frontu nebola ústavne prípustná a politické vedenie o nej ani neuvažovalo.

5 „Můj pohled na Únor a jeho následky je proto třeba číst s tímto osobním sociálnědemokratickým předznamenaním“ (Hrubý 2018, 44). 
Nenastal kompromisný prechod na iný režim a až dva dni po symbolickom generálnom štrajku odhlasovalo Federálne zhromaždenie vypustenie článku 9 o vedúcej úlohe KSČ z ústavy, potom došlo k postupnej kapitulácii (Hrubý 2018, 356 - 358).

Klúčom k pochopeniu problematiky demokracie a politickej plurality je preskúmanie historického sporu medzi dvoma líniami politickej lavice. Historický prvým politickým vystúpením pracujúceho l'udu bola Parížska komúna. Môže fungovat' samospráva l'udu?

\section{0. výročie Parížskej komúny a idea samosprávy}

Komúna je v podstate niečo ako mestská rada. Komunardi zaviedli komú$\mathrm{nu}$, teda kolektívne rozhodovanie, $\mathrm{v}$ dnešnej terminológii participatívnu demokraciu. Sedemdesiat dní dokázalo, že obyčajní l'udia, vtedy mestský proletariát, sú schopní uchopit' vládu a vládnut' bez vtedajších elít. To bolo vtedy a je aj dnes nežiadúce, nevídané, neslýchané, preto Krvavý týždeň, ktorý pripomína Múr komunardov na cintoríne Pére Lachaise; v dejinách sa opakuje a bude opakovat'. K aktom násilia dochádzalo aj zo strany komunardov, to ale vyplývalo z historickej situácie. Komúna ako „sociálna republika" uskutočňovala opatrenia, ktoré by sme dnes označili ako sociálno-demokratické. Zaviedla symbol - červenú vlajku, vedenie tovární mali prevziat' robotníci, políciu a armádu nahradil ozbrojený l'ud, zaviedla rovné mzdy, dostupné byty, zákaz detskej práce, bezplatné vzdelanie a volebné právo žien; d’alej odluku cirkvi od štátu a zabavila cirkevný majetok, ale neznárodnila banky a súkromné vlastníctvo. Tento program bol na svoju dobu radikálny, podla súčasných kritérií umiernený, čomu nasvedčuje aj dobová kritika, že chybou bolo nevykonanie radikálnejších opatrení vo vzt'ahu k vlastníctvu a politickému režimu.

Parížska komúna nebola diktatúrou proletariátu, to je zavádzajúca politická konštrukcia. Požiadavku revolučnej diktatúry pravdepodobne po jakobínoch z konca 18. storočia znovu nastolil revolucionár Auguste Blanqui. V decembri 1848 v prezidentských vol'bách zvítazil L'udovít Bonaparte a hned' začal uskutočňovat' štátny prevrat. Blanqui prestal pripisovat' význam všeobecnému volebnému právu, pokladal ho za nebezpečné. Dospel k záveru, že prechod k socializmu si vyžaduje revolučnú diktatúru, bez ktorej nemožno udržat' moc (Molčanov 1989, 262). F. Engels sa nechal uniest' $\mathrm{v}$ deň dvadsiateho výročia komúny a Úvod k Marxovej práci Občianska vojna vo Francúzsku (1891, t. j. po Marxovej smrti) zakončil pôsobivou aklamáciou: „V poslednom čase sa nemecký filister opät’ poriadne zlakol slov diktatúry proletariátu. Nuž dobre, páni, chcete vediet', ako 
vyzerá táto diktatúra? Pozrite sa na Parížsku komúnu. To bola diktatúra proletariátu." ${ }^{6}$

Marx nikdy nepoužil termín „diktatúra proletariátu“ systematicky ako nevyhnutné štádium vývoja, ani sa v jeho spisoch nevyskytuje. Výnimkou je svojho času povinne citovaný List Weydemaierovi z roku 1852, v ktorom obhajuje v polemike existenciu tried; túto, rovnako ako triedny boj, však neobjavil on sám. Za svoj prínos považuje, že triedny boj nevyhnutne vedie $\mathrm{k}$ diktatúre proletariátu a sama táto diktatúra je len prechodom $\mathrm{k}$ beztriednej spoločnosti. ${ }^{7}$ Marx, ktorý mal klasické vzdelanie, vedel, že diktatúra v antike bolo dočasné opatrenie v čase krízy na 1-2 roky. Chápal teda diktatúru proletariátu ako prechodné štádium. Samosprávu ako pokus Parížskej komúny o zásadne novú formu vlády stalinský a poststalinský režím, pre ktorý sa používa označenie „socializmus“, v post-štádiu s adjektívom „reálny“ príliš neakcentoval, až na zriedkavé ideologické kampane.

Ako je známe, Marx a Engels nechceli konjunkturálne aktualizovat' Manifest Komunistickej strany. Oprávnene, ide o historický dokument. S jednou výnimkou prehodnotenia skúsenosti Parížskej komúny: „robotnícka trieda nemôže jednoducho prevziat' hotový štátny aparát a uviest’ ho do chodu pre svoje vlastné ciele“. ${ }^{8}$ Toto si osvojil Lenin, prevzal Engelsov výrok, na základe toho dospel k určitým záverom, ktoré poznamenali osud komúny resp. socializmu do súčasnosti. Dodnes prevláda Leninova interpretácia z tretej kapitoly Štátu a revolúcie, že to bol prvý historický pokus o zavedenie diktatúry proletariátu, ktorá je nevyhnutným štádiom prechodu od kapitalizmu ku komunizmu a je systémovou charakteristikou silného socialistického štátu; ide o korekciu Marxovej tézy o zániku štátu štát nezaniká, ale odumiera. Lenin sa pod vplyvom okolností rozhodol, ako je zdôvodnené v diele Čo robit', vyriešit' otázku hegemóna revolúcie vytvorením avantgardnej strany, ktorá mala byt' pokračovatel'om konšpiratívnej organizácie bol'ševikov. Na základe štúdia sa domnievam, že boľševici a osobitne Lenin sa obávali, že ich revolúcia by mohla skončit’ ako Parížska komúna v krátkom čase. Preto musela byt' potlačená Kronštadská vzbura, na čom sa rovnou mierou podieláli Lenin a Trockij. Nasledoval zákaz frakcií v strane. Lenin vel'mi dobre poznal Marxovu teóriu a vedel, že pre

Marx - Engels, zv. 3, 1977, s. 300.

Na tento list sa odvoláva Lenin v druhej kapitole Štát a revolúcia. Marx - Engels, tamže, zv. 2, s. 569.

8 Predslov (k nemeckému vydaniu z roku 1872). In: Marx, K. - Engels, F.: Vybrané spisy v piatich zväzkoch. Zv. 1, Pravda, Bratislava 1977, s. 332. Marx v liste L. Kugelmannovi (apríl 1871): predpokladom každej ludovej revolúcie je, že sa „už nepokúsi odovzdat' byrokraticko-vojenskú mašinériu z jednej ruky do druhej, ale pokúsi sa ju rozbit'" (Tamže, Zv. 3, s. 555). 
Rusko sa nehodí, preto sa nádejal na pomoc nemeckého proletariátu, lenže pokusy o socialistickú revolúciu boli krvavo potlačené a priviedli k moci Hitlera. Soviety ako forma participatívnej demokracie boli vo fáze stalinskej konsolidácie impéria zlikvidované, výkon moci prevzala stranícko-štátna byrokracia, o ktorej v podobe nomenklatúry by sa dalo diskutovat' ako o novej vládnúcej triede, rozštiepenej na technokratov a byrokratov. V dôsledku tohto boja sa v Rusku etablovala tá najhoršia oligarchická podoba kapitalizmu a neboli prekonané relikty tradičnej autority (cár, generálny tajomník, prezident).

Pokial' ide o vznik sovietov (совет - rada), treba pripomenút' ešte jednu historickú udalost' - januárovú ruskú revolúciu roku 1905. Počas prvej ruskej revolúcii, ktorej začiatok je označovaný ako „krvavá nedela“ 22. januára 1905, spontánne vznikali soviety čiže rady pracujúcich. Lenin bol vtedy v emigrácii ako predstavitel' sekty profesionálnych revolucionárov, osobne sa presvedčil po dočasnom návrate o malom a nedostatočnom vplyve bol'ševikov. ${ }^{9}$ Tieto soviety ako-tak fungovali dva roky, samozrejme boli potlačené, ale myšlienka zostala. A ožila v roku 1917. Známe je Leninovo heslo Komunizmus rovná sa soviety plus elektrifikácia. Hannah Arendt pripomína, že uvedené heslo je pozoruhodné to, čo neobsahuje: úlohu strany a budovanie socializmu. Lenin prekonal vernost' marxizmu a ideologickú zaslepenost', ked' považoval technický pokrok za spôsob riešenia sociálnej otázky v Rusku a systém rád za novú štátnu formu, ktorá sa sformovala v priebehu revolúcie. Nemarxistické oddelenie hospodárstva a politiky predpokladal Lenin tak, že oslobodenie od chudoby možno zvládnut' technickými prostriedkami, zavedenie novej štátnej formy technika nevyžaduje, cielom rád je sloboda. Alternatívu rozumnej neideologickej industrializácie Ruska a alternatívu slobodných štátnych orgánov však Lenin obetoval v mene Strany, všetku moc získal stranícky aparát. Lenin sa netajil tým, že svoj pôvodný názor zmenil preto, lebo mu viac

9 V sovietoch mali prevahu menševici pred bol’ševikmi, predsedom Petrohradského sovietu bol mladý Trockij. Revolucionári si uvedomovali, že ruský proletariát je málo početný a nedostatočne vyspelý, rol’níci zaostalí; podla Trockého ak by sa dostala k moci radikálna populistická strana, síce by mohla začat' zavádzat' socializmus, ale nedokáže udržat' moc, pokial' sa permanentná socialistická revolúcia nezačne šírit’ vo vyspelej západnej Európe. Menševici boli presvedčení, že napriek slabosti práve buržoázno-liberálnej strana by mala prevziat' moc po zvrhnutí absolutizmu. Lenin ich obvinil z chvostizmu, ruskú buržoáziu považoval za neschopnú naplnit' historický údel buržoáznej revolúcie; oponoval koncepciou „revolučno-demokratickej diktatúry proletariátu a rol'níctva". Lenin chcel využit' radikalizované masy na transformáciu bol'ševikov, ktorí vtedy predstavovali skôr agitačnú skupinu, na masovú proletársku stranu. 
záležalo na elektrifikácii než na moci strany. Bol presvedčený o tom, že primitívny l'ud v ekonomicky zaostalej krajine nedokáže zvládnut' boj proti chudobe v podmienkach politickej slobody, resp. považoval za ilúziu, že je možné súčasne porazit' chudobu a zaviest' slobodu. Lenin bol posledným dedičom Francúzskej revolúcie, konal v duchu revolučnej tradície, ked' nové orgány slobody obetoval strane, ktorá lud oslobodí od chudoby; jeho zlyhanie chápe Arendtová ako súčast' tragického výsledku tejto revolúcie (Arendt 1965, 82-83). Októbrová revolúcia vyústila do občianskej vojny, ktorú vyhrali bolševici. Lenin a Stalin udržali Sovietsky zväz v podstate $\mathrm{v}$ hraniciach cárskeho impéria, čo nebolo $\mathrm{v}$ pláne imperiálnych mocností Západu. Cenou za to bolo pretrvávanie vojnového komunizmu ako súčasti ekonomického a politického štátneho zriadenia, ako aj zúfalá, ale úspešná idea budovania socializmu v jednej krajine, ktorá znamenala vydrancovanie rol'níctva (Preobraženského plán), lež úspešnú industrializáciu. Komunistické strany, orientované viac či menej na Moskvu, majú problém s politickou legitimitou v dôsledku krachu sovietskeho modelu socializmu. Alternatívu predstavuje iba spôsob globalizácie, ktorý presadzuje Komunistická strana Číny. Rusko je od konca 19. storočia vystavené Thukydidovej pasci („The Thucydides Trap“ G. Allisona sa nevzt'ahuje iba na Čínu). Obavy z úspešnej modernizácie cárskeho Ruska mali Briti už pred prvou svetovou vojnou. Operáciu „Unthinkable“ plánoval Churchill s nemeckými vojnovými zajatcami ako pokračovanie druhej svetovej vojny a o nespravodlivosti príliš vel'kého podielu prírodného bohatstva, ktorým disponuje Rusko, hovorila nedávno vo funkcii ministerky zahraničia USA pani M. Albrightová. Multipolárny svet sa rodí t’ažko a konfliktne.

\section{Schizma l'avicových politických strán}

Prvá internacionála bola založená v Londýne v roku 1864, mali v nej prevahu anarchisti a marxisti boli v menšine, pre nezhody medzi nimi najmä ohladom zániku štátu ju Marx rozpustil v roku 1876. Druhá internacionála bola založená v Paríži s vylúčením anarchistov, odvtedy sa datuje spor medzi autoritárskym a libertariánskym socializmom. Rozhodujúcim obdobím pre formovanie lavicových politických strán bol koniec devätnásteho a začiatok dvadsiateho storočia až po rozpad Druhej internacionály v dôsledku vypuknutia prvej svetovej vojny (1916). T. G. Masaryk sa nemýlil, ked' svetovú revolúciu stotožnil s prvou svetovou vojnou (1914 - 1918), ale mýlil sa, ked’ spor o spôsob modernity vymedzil ako „části velikého boje za svobodu a demokracii, boje mezi theokratickým absolutismem a humanitním demokratismem", hoci naozaj zanikli tri teokratické monarchie (Masaryk 1928, 500). Po vojne vznikli dve internacionály: bol’ševici 
a revolucionári založili v roku 1919 Tretiu internacionálu (Kominternu KI) a sociálnodemokratické strany sa v roku 1923 združili v Socialistickej robotníckej internacionále (SRI). Podmienky pre vstup do KI sformuloval Lenin na druhom kongrese (1920). Jednotlivé komunistické strany sa stali iba sekciami KI, boli podriadené centru v Moskve a tak sa stali vykonávatel'mi politiky ruských bol'ševikov. Každá strana musela mat' názov „komunistická“, pretože KI vypovedala rozhodný boj všetkým „žltým“ sociálnodemokratickým stranám, ktoré zradili robotnícku triedu. Toto stanovisko prešlo peripetiami až do rozpustenia KI Stalinom v roku 1943, to presahuje rámec našej štúdie. SRI predstavovala vol'né združenie „demokratických strán", zanikla v dôsledku otrasu z Mníchovskej dohody pred druhou svetovou vojnou. Socialistická internacionála, založená roku 1951 vo Frankfurte, funguje dodnes a združuje 134 politických strán a organizácií. Okrem SI existujú roztrieštené trockistické skupiny, ktoré sa vydávajú za Štvrtú internacionálu. Komunistické strany, orientované viac či menej na Moskvu, majú problém s politickou legitimitou v dôsledku krachu sovietskeho modelu socializmu. Alternatívu predstavuje iba spôsob globalizácie, ktorý presadzuje KS Číny. Všetky modifikácie KI sa vyznačovali doktrinárstvom, záujem o svetovú revolúciu a v skutočnosti geopolitické záujmy impéria znamenali pre jednotlivé strany pokial' sa podriadili, hrozbu pádu do sektárstva, vážne konflikty až po stratu členstva a hlasov.

Nedávne sté výročie založenia KSČ bolo príležitost'ou na bilancovanie resp. hodnotenie pôsobenia strany, ktorá markantným spôsobom zasiahla do politického života oboch našich národov. Bohumír Šmeral, dominujúca postava českého robotníckeho hnutia, bol austromarxista. Aj preto po vzniku Prvej ČSR bol jeho politický vplyv obmedzený, lebo mu vyčítali jeho predstavu možnej demokratickej reformy Rakúska a sociálnodemokratickej internacionálnej strany rôznych národov. Socialistické strany získali vo vol'bách v roku 191947 \% hlasov, čo sa však neprejavilo pri riešení kritickej sociálnej situácie. Radikálne riešenie ponúkala ideológia bol'ševikov a heslá Októbrovej revolúcie. Začali sa ozývat' hlasy na odchod zo sociálnej demokracie a prijatie podmienok Kominterny. Šmeral chcel pretvorit' stranu zvnútra, postavit’ do jej čela komunistické vedenie, vytvorit' revolučné a internacionálne socialistické hnutie za uskutočnenie socializmu československou cestou, využívat' ruské skúsenosti v našich špecifických podmienkach (Mencl - Hájek - Otáhal - Kadlecová 1990, 92-93). KSČ po zlučovacom zjazde $\mathrm{v}$ roku 1921 prijala 21 podmienok vstupu do KI, stala sa masovou stranou, mala 300 tisíc členov. Šmeral na zjazde politiku stany uviedol nasledovne: „Jsme více než politická strana. Jsme předvoj nového života. Tvoříme nové poměry, chceme tvořit také nové 
lidi." ${ }^{10}$ Už na V.kongrese KI v roku 1924 čelila KSČ kritike pre nedostatočnú bol'ševizáciu (podriadenie centru) a nedostatočný boj proti sociálnodemokratickým prežitkom. Na V. zjazde KSČ v roku 1929 ovládlo stranu nové vedenie mladých komunistov na čele s K.Gottwaldom, nastala kritika oportunizmu a následne stranícke čistky. Cielom sa stalo nastolenie diktatúry proletariátu, ako to požadovala KI, hoci na to neboli objektívne podmienky. Zo 150 tisíc členov ostalo 25 tisíc, vylúčených bolo aj 7 lavicových spisovatelov.

Petr Pithart v diskusii použil termín „sebeabdikace“ strany. Takejto autoabdikácie sa strana dopustila viackrát. Napríklad mala masovú podporu po druhej svetovej vojne vzhladom na zástoj v odboji ako aj zradu Západu v Mníchove. Generálny tajomník R. Slánský budoval masovú stranu, záujem bol o prijímanie sociálnych demokratov, spolu s predsedom strany K. Gottwaldom hlásali vlastnú československú cestu k socializmu. Vol'by v roku 1946 podla Hrubého všetkých prekvapili (Hrubý 2018, 41), lebo KSČ a KSS získali až 38 \% hlasov. Zo špecifickej cesty k socializmu nebolo nič, studená vojna neposkytovala priestor na odchýlky, neskôr nasledovali čistky proti infiltrácii sociáldemokratizmu. ${ }^{11}$ Masovú podporu mala KSČ aj v roku 1968 na základe Akčného programu, po invázii a prijatí dokumentu „Poučenie“ nasledovali čistky, ktoré postihli $21 \%$ členov a drasticky jej intelektuálny potenciál. Zjednodušene sa ponúka konštatovanie, že KSČ mala podporu, ked' kráčala s l'udom (v straníckej frazeológii), inak povedané, ked' mala demokratickú spätnú väzbu a riadila sa viac pragmatizmom ako ideologickými dogmami. Všetky tieto pokusy však boli vzhl'adom na nepriaznivé externé faktory zastavené. Takže súhlasím s Borisom Zalom, že „komunisti ako politický prúd v podstate zanikli“ (Zala 2021). Zala štylizuje cestu návratu po 80-ročnej odluke „po tragickej ceste bol’ševického experimentu spät’ ku sociálnej demokracii“, symbolom tohto návratu bol A. Dubček (Zala 2021). ${ }^{12}$ Nie som si istý, či vzhl'adom na okolnosti a súčasný stav sociálnodemokratickej a obecne l'avicovej politiky na Slovensku, išlo o návrat úspešný.

10 Pozri Jancura, V.: 100 rokov od vzniku KSČ: "Sme viac než politická strana..." Pravda, denník 17. 5. 2021.

11 Hrubý pripúšta pred februárom 1948 istú nezávislost' pri uskutočňovaní sovietskeho modelu socializmu, vrátane limitovanej parlamentnej cesty k socializmu obmedzenej rámcom Národného frontu. Lenže Akčný program KSČ z apríla 1968 petrifikoval zmeny nastolené po februári 1948. Spomienka na „československú cestu k socializmu“ sa nestala programom reformného socializmu (Hrubý 2018, 202).

12 Zala, B.: Sto rokov od založenia KSČ. Denník Pravda 30.5.2021. Doc. Borisovi Zalovi d’akujem za diskusiu a cenné pripomienky, hoci máme aj rozdielne názory. 
Čím sa zásadne odlišovala sociálno-demokratická lavica od komunistickej? Najvýznamnejším reformátorom socializmu bol Eduard Bernstein. Bol to vzdelaný marxista, ktorá dával prednost' reálnej politike sociálnodemokratickej strany pred utopickým konečným cielom; Lenin ho zaradil do oportunistického tábora a označil za renegáta. Hrubý podrobne cituje z Bernsteina a dokumentuje, že práve on bol prvým autorom koncepcie „demokratického socializmu“, pričom predpokladal „rozšíření demokracie politické i na půde hospodářské" (Hrubý 2018, 136). Východisková téza E. Bernsteina spočíva v tom, že ,... demokracia je v ovela väčšej miere predpokladom socializmu, než sa bežne predpokladá, t. j. nie je iba prostriedkom $\mathrm{k}$ jeho uskutočneniu, lež samou jeho podstatou. ${ }^{13}$ Reformistický program nemeckej SD (Bad Godesberg 1959) bol inšpirovaný Bernsteinovým evolučným socializmom, v aktuálnej verzii prostredníctvom teórie konvergencie, ktorá bola vtedy populárna, pretože jej nahrával welfare state v západnej Európe. Konvergencia sa stala ilúziou, ked' v rámci doznievajúcej povojnovej konjunktúry začal pôsobit’ Marxov zákon klesajúcej miery zisku. Korporácie, pre ktoré národné hranice boli vždy prekážkou, začali od sedemdesiatych rokov konat’ v globálnom rámci. Ekonomickým stimulom bolo znižovanie nákladov. Povojnová konjunktúra v západnej Európe bola do značnej miery spätá s koncepciou sociálneho štátu. Politiku sociálneho štátu začali uskutočňovat' sociálnodemokratické vlády v škandinávskych krajinách v podobe sociálneho partnerstva už v tridsiatych rokoch minulého storočia. Po druhej svetovej vojne sociálne programy, ktoré presadzovali sociálnodemokratické strany, boli čiastočne inšpirované studenou vojnou a opatreniami v socialistických krajinách. Tak sa etablovala dočasná ilúzia konvergencie odlišných spoločenských systémov. Po diskreditácii reálneho socializmu v roku 1989 absentovali politické a ideologické dôvody udržiavania sociálneho štátu, ktorý sa z ekonomického pohladu nastupujúceho neoliberalizmu javil ako príliš drahý a neefektívny. Ideológia neoliberalizmu, vidina univerzálnej trhovej spoločnosti, narazila na svoje limity, lebo nedokáže čelit’ kumulácii súčasných globálnych kríz a katastrof.

Spor o spôsob modernity svojím spôsobom vyvolala Francúzska revolúcia a jej oneskorená verzia v ruskej Októbrovej revolúcii. Podla môjho odhadu je naša súčasná situácia do určitej miery podobná ako na sklonku dvadsiatych a v tridsiatych rokoch minulého storočia. "La belle Époque", ktorá skončila neskončenou vojnou, bola založená na osvietenstve, na technokratickom optimizme, na kantiánskom obdive k matematike

13 ,.... ist die Demokratie in weit höherem Grade Voraussetzung des Socialismus, als es vielfach noch angenommen wird, das heisst sie ist es nicht nur als Mittel, sondern auch als Substanz" (Bernstein 1973, 199). 
a racionalizovanej deontologickej etike, na hegeliánskom boji protikladov a problematickej dialektike návratu. J. Patočka, ktorý ako jeden z mála nastavil zrkadlo dejinám ako „krvavému“ 20. storočiu, načrtol kritiku patológie modernity svojím konceptom Nadcivilizácie. ${ }^{14}$ Filozof, zrejme ovplyvnený Spenglerom, dospel k záveru, že pokračovanie v štýle starej Európy je odsúdené na zánik. Liberalizmus sa pokúša metodicky pokračovat' v starej tradícii z doby imperiálnej Európy v zmysle tendencie bránit' prevahu prvej priemyselnej mocnosti sveta silou. Komunizmus interpretoval Patočka ako jeden $\mathrm{z}$ variantov nadcivilizačného radikalizmu, $\mathrm{v}$ súčasnosti by za nový variant kýženého považoval súčasný liberálny projekt trhového fundamentalizmu (Arnason 2010, 43-44). Liberálny civilizačný model, vo svojom vnútri moderantný, ktorý ohlasovali filozofi - „radikálni osvietenci 17. storočia“ - sa navonok po druhej svetovej vojne počas studenej vojny a osobitne po jej skončení v 90-tych rokoch transformoval do radikálnej nadcivilizácie, ktorá si nárokuje univerzálne impérium v mene globalizácie, nemá však patričné geopolitické ani kultúrne zakotvenie. J. Patočka v dobe povojnovej zaviedol rozlišovanie: ideológia je vonkajšia sila, ktorá vedie k určitému ciel'u, idea je vnútorný priestor existencie človeka. Fašizmus nemá ideu, je založený na technickom ovládaní sily vrátane človeka, socializmus je „zároveň idea, ideologie i pojetí člověka" (Patočka 1946) ${ }^{15}$. Patočka poukázal na hrozbu, ktorú predstavuje ideológia bez idey, resp. ked' sa vymkla kontrole ideou. Filozof tak nastavil kritérium, ktoré sa vztahuje tak na stalinizmus, ako na poststalinský normalizačný režim. Toto kritérium osudovo prežívali aj mnohí komunisti, nielen tí z konjunkturálnych politických dôvodov prenasledovaní. „Soudím, že rozšíření takové ideologie musí vždy znovu vésti k pokusům fašismu podobným; možná že chytřejším a úspěšnějším, ale v podstatě

14 Patočkov rukopis z 50-tych rokov Nadcivilizace a její vnitřní konflikt anticipoval civilizačnú analýzu, inšpiruje súčasnú historickú sociológiu. Na základe konceptu „stupňovanej racionalizácie“ M. Webera rozlišuje dva spôsoby modernity: moderantnú a radikálnu. Ide o spôsob presadzovania univerzality nadcivilizácie - moderantnost' alebo radikálnost'. Moderantná nadcivilizácia nemieni racionálne vyplnit’ celý život, všetky životné princípy, dokáže si osvojit' neracionalizovatel'né a predsa podstatné spolupodmienky l'udskosti od doterajších civilizácií; jej univerzálnost' je netotálna. Radikálna nadcivilizácia nárokuje totálne ovládnutie života v mene radikálnej premeny spoločnosti; zavádza nové hybridné náboženstvo, čím vylučuje kritické myslenie (Patočka 1996, 250-257).

15 Článok J. Patočku z roku 1946 „Ideologie a život v ideji“. Citované podla J. Novotný: Filozofova tichá válka. In: Listy 2007, č. 4. V anglickom preklade, ktorý vyšiel v roku 2020:

„But socialism is at once an idea, an ideology, and a concept of Man“ (Patočka 2020,44) 
vždy stejně lidsky zoufalým, poněvadž v nich není místa pro ideu" (Patočka 1946) ${ }^{16}$. Varovanie J. Patočku sa v podstate zhoduje s varovaním Adorna a Horkheimera v Dialektike osvietenstva.

V roku 1944 Adorno a Horkheimer vytýčili otázku, prečo l'udstvo upadá do nového druhu barbarstva (Adorno - Horkheimer 2009, 11). Osvietenstvo je totalitárne aj preto, že stotožňuje myslenie s matematikou, ktorá sa stala absolútnou inštanciou. „Myšlení sa zvěcňuje k samočinně probíhajícímu, automatickému procesu, soupeřícímu se strojem, který sám vytváří, takže tento stroj může nakonec myšlení nahradit" (Adorno Horkheimer 2009, 36-37) V roku 1969 upozornili na nový nástup totalitarizmu, „vývoj k totálnej integrácii“ hrozí, že sa naplní prostredníctvom diktatúr a vojen (Adorno - Horkheimer 2009, 9). Pritom už vo vydaní z roku 1947 autori varovali: „Ale až bude po všem, v Evropě se vůbec nemusí rozšiŕit duch svobody. Evropské národy mohou být stejně xenofobní, kultuře nepřátelské a pseudokolektivistické, jako byl fašizmus, proti němuž se musely bránit. Ani jeho porážka nutně nezastaví pohyb lavíny“ (Adorno - Horkheimer 2009, 2014).

U Adorna nejde iba o sklamanie nad krachom revolučných nádejí, ale o zhrozenie z katastrofického vyvrcholenia civilizácie. Filozof odmieta vykonštruované univerzálne dejiny. „Bolo by cynické tvrdit’, že v dejinách sa manifestuje nejaký plán na lepší svet, ktorý ich zjednocuje. ... Niet žiadnych univerzálnych dejín, ktoré by postupovali od divošstva k humanite, ale existujú dejiny postupujúce od pästného klinu k megabombe. Dejiny končia totálnou hrozbou, ktorú predstavuje organizované l'udstvo vo vzt'ahu k organizovaným l'ud’om, sú stelesnením diskontinuity“ (Adorno 1973, 320). Filozof $v$ šest'desiatych rokoch viackrát varoval pred potenciálom pravicového extrémizmu, že spoločenské predpoklady pre existenciu fašistických hnutí stále existujú. Ide o prejav toho, že podla spoločensko-ekonomického obsahu sa demokracia k dnešnému dňu nikde naozaj a naplno nerealizovala, ale ostala formálnou; fašistické hnutia možno vnímat’ ako stigmy, ako jazvy demokracie, ktorá dodnes v plnej miere nenapíňa svoju vlastnú definíciu (Adorno 2019, 13). Osvietenské myslenie sa vyznačuje postulátom spoločenského pokroku, inak povedané v duchu Condorceta, že epochy sa striedajú ako schodíky, že história prebieha po vzostupnej línii, k čomu treba iba definovat' príslušné kritérium pokroku ako takého.

16 Článok J. Patočku z roku 1946 „Ideologie a život v ideji“. Citované podla J. Novotný: Filozofova tichá válka. In: Listy 2007, č. 4. V anglickom preklade, ktorý vyšiel v roku 2020: „I think that the expansion of such an ideology must always again lead to similar attempts at fascism, maybe more clever and more successfull, but essentially always to similarly humanly desperate attempts, since there is no place in them for the Idea" (Patočka 2020,47). 
História sa neodohráva priamo, ale zložito a vo viacerých variantoch, nestrácajú sa ani vektory, ktoré sa neuplatnili, súčastou bojov živých sú tiež naši predkovia a predchodcovia. Ilúzie o moci prírodných vied, vlastné 19. storočiu spolu s prehnanou vierou $\mathrm{v}$ moc rozumu viedli k postulovaniu historickej nevyhnutnosti. Tieto postuláty osvietenstva sú v 21. storočí prekonané a nebojím sa konštatovat', že zdiskreditované, a to nielen v rámci ortodoxného marxizmu. Udalosti 20. storočia podla Adorna vyvolali ideu historickej totality v podobe kalkulovatel'nej ekonomickej nevyhnutnosti. Táto totalita však v skutočnosti predstavuje iba „sociálne nevyhnutné zdanie" (Adorno 1973, 323), od ktorého sa kritické sociálne vedomie musí oslobodit'.

Termín demokracia počas studenej vojny bol a doteraz je predmetom ostrého nielen ideologického, ale aj ozbrojeného boja. V súčasnosti, po ratifikácii dvoch najvýznamnejších dokumentov OSN, definujúcich občiansko-politické a sociálno-kultúrne práva v roku 1976, je politická demokracia spätá s dodržiavaním l'udských práv. Demokracia odvodzuje legitimitu od vôle l'udu, ktorá sa vyjadruje prostredníctvom pravidelných volieb. Liberálna demokracia sa zakladá na občianskej, nie na sociálnej, rovnosti (J. Locke, J. J. Rousseau) a neviaže sa na kapitalizmus. Robert Reich, ktorý bol ministrom práce za prezidentovania B. Clintona, upozorňuje, že výlučne l'udia môžu byt' občanmi a teda majú nárok podielat' sa na demokratickom rozhodovaní. Tento nárok nemajú korporácie. (V USA majú podnikatel'ské subjekty ústavné práva, podobné právam občanov). Podl'a Reicha rozhodnutie $\mathrm{v}$ prospech demokratického kapitalizmu si vyžaduje oddelit' kapitalizmus od demokracie a chránit' hranicu medzi nimi (Reich 2008, 167, 223). Špecifické spojenie medzi kapitalizmom a demokraciou sa historicky vyvíjalo a medzi jednotlivými krajinami sú politické rozdiely. J. Rawls navrhuje, aby liberálne národy (skôr „štáty“ - pozn. L. H.) tolerovali iné prijatel'né spôsoby usporiadania spoločnosti, pokial' spĺňajú určité podmienky politického práva a spravodlivosti. Tolerancia znamená uznat' tieto neliberálne spoločnosti ako rovných účastníkov v Spoločnosti národov a vyhýbat' sa uplatňovaniu sankcií. Fungovanie demokracie v rámci kapitalizmu má totiž presne vymedzené mantinely, čo potvrdzujú historické skúsenosti (Rawls 2009, 93). Možno vyslovit’ názor, že vyššia forma demokracie na rozdiel od reprezentatívnej, ktorá poskytne široký priestor pre výrobnú a politickú samosprávu, sa vyvinie až po eliminácii ekonomickej a sociálnej nerovnosti, t. j. po kapitalizme. Ilúzia historickej totality je síce potrebná ako „zdanie“, ale je zároveň kontraproduktívna a nebezpečná. Napriek tomu, že Rusko buduje usilovne kapitalizmus a vol'by uznali za platné medzinárodní pozorovatelia, pokračuje rétorika studenej vojny; F. Zakaria situáciu výstižne charakterizoval ako studený mier. A v Rusku 
na rozdiel od Číny nie sú komunisti pri moci. Napriek tomu pretrváva naratív o slobodnom svete, hoci realita mu odporuje, o tzv. boji za demokraciu, čo má byt' civilizačným poslaním Západu. Ak aj zavrhneme eurocentrizmus v rámci westernizácie, neznamená to popierat' určitú mieru civilizačného poslania modernity.

Podl'a môjho názoru je dost' dôkazov, že sa nemožno odvolávat' na historickú spätost' kapitalizmu a demokracie. Tento trend je podmienený špecifickým historickým rámcom, ktorý dovol'uje kontrolovanú demokraciu ako súčast' spoločenskej zmluvy. V správe Trilaterálnej komisie o kríze a ovládatel'nosti demokracie (1975) sa píše: „Budeme nútení uznat', že existujú žiadúce obmedzenia vo vzt’ahu k ekonomickému rastu. Rovnako existujú žiadúce možné limity, pokial' ide o nekonečné rozširovanie politickej demokracie. Demokracia bude mat' dlhší život, ak bude fungovat' vyváženejšie" (Crozier - Huntington -Watanuki 1974, 115). Stabilizátorom demokracie podl'a učebníc je stredná trieda, ktorá dokáže využívat' jej výdobytky. Lenže stredná trieda je ohrozená a prekarizovaná, rovnako ako robotnícka trieda. A štúdia je dôkazom, že demokraciu bude vládnuca oligarchia akceptovat', pokial' disponuje funkčným panoptikom, ovela sofistikovanejším než bolo to Benthamovo, založené na samote a izolácii v kombinácii s ilúziou permanentného dohl'adu. Tento nástroj manipulácie zaručuje priaznivý volebný výsledok bez ohladu na to, či je pri moci lavica alebo pravica. „Fašizmus, či už v klasickej podobe v minulom storočí alebo jeho možný variant, neofašizmus 21. storočia, predstavuje špecifickú odpoved' na krízu kapitalizmu“ (Robinson 2019, 163). Demokratického divadla sa vládnuca oligarchia v prípade potreby vel'mi lahko vzdá v prospech neofašistického (pravicového) populizmu.

Sociálnodemokratické strany v západnej Európe boli úspešné tridsat' „zlatých“ rokov sociálneho štátu. Lenže po nástupe neoliberalizmu nedokázali sformulovat' nový program, ocitli sa vo vákuu, posunuli sa doprava, čiastočne prijali pravicovú rétoriku, napríklad tézu o „rozptyle bohatstva“ - čím viac je vel'mi bohatých, tým viac sa vraj zlepší postavenie ostatných (Rawls - „menej zvýhodnených“). Toto sa ukázalo ako nezmysel a klamstvo, nerovnosti sa prehlbujú a prekarizuje sa okrem pracujúcich aj stredná trieda. N. Fraserová uvádza, že progresívny neoliberalizmus sa rozvinul v USA za ostatných tridsat' rokov od zvolenia B. Clintona (1992). Vo svojej americkej podobe sa zakladá na spojení nových sociálnych hnutí (feminizmus, antirasizmus, multikulturalizmus, LGBTQ) so silami kognitívneho a finančného kapitalizmu (Wall Street, Silicon Valley, Hollywood), výsledkom čoho je zdecimovanie priemyselnej výroby a pauperizácia strednej triedy. Minulý režim štátom riadeného kapitalizmu dával vládam možnost' podriadit' krátkodobé úsilie súkromných firiem dlhodobému cielu 
trvalejšej akumulácie, súčasný režim umožňuje globálnym financiám, aby riadili vládu a spoločnost' v prospech dočasných záujmov súkromných investorov. Útok na sociálny štát a sociálne zabezpečenie bol zamaskovaný emancipačnou charizmou, ktorú poskytli nové sociálne hnutia (Frazer 2017, 52-56). Tento postup možno označit’ ako sút'až menšín a kvázimenšín o postavenie „najmenej zvýhodnených“, aby sa mohli dožadovat’ kompenzácie niekedy aj v bizarnej podobe.

Termín „liberálny fašizmus" vznikol v tridsiatych rokoch minulého storočia, pripisuje sa utopistovi a sociálnemu kritikovi H. G. Wellsovi. Na príklade USA „progresívci sa dopúštali mnohých skutkov, ktoré by sme dnes objektívne považovali za fašistické, kým fašisti často konali tak, že by sme ich skutky dnes objektívne považovali za progresivistické (Goldberg 2009, 16). Dnes za „neomarxistov“ označujú tzv. progresivistickú l’avicu, ktorá namiesto kritiky nespravodlivej ekonomickej a politickej nerovnosti hlása pochybne interpretovanú genderovú rovnost' a túto militantne presadzuje až deformuje výklad l'udských práv v prospech niektorých menšín prostredníctvom pozitívnej diskriminácie. Pripomeniem bizarnú formu rasizmu, ktorá je založená na výlučnosti, aj ked’ môže byt' čiastočne oprávnená (čierny volič v USA - vtedy oslobodený otrok - bol 3/5 človek podla Filadelfskej konvencie 1787, toto bolo zrušené troma ústavnými dodatkami až v rokoch 1865-1869).) Ďalej extremistický zelený fašizmus alebo ničenie artefaktov $v$ mene prepisovania histórie.

Takže sme sa opät' ocitli v situácii, ktorú pred sto rokmi pomenoval Gramsci ako interregnum čiže obdobie nestability, kedy nič nie je isté, osvedčené recepty zlyhávajú a nové nemáme k dispozícii. Vtedy hrozia svojvol'né ideologické konštrukcie, ktoré sa v medziobdobiach „uplatnia len v dost' výstredných a čudesných spojitostiach“ (Gramcsi 1988, 46). Sociologickú fikciu revolučnej robotníckej triedy ako prvý spochybnil pred storočím Horkheimer v rámci Frankfurtskej školy (Honneth 2020, 81, 72). Pokial' ide o sociálnu demokraciu, táto sa ocitla v defenzíve, strany strácajú svojich voličov, nastupujú populisti, pravicoví a aj takí, ktorí sa tvária ako lavica. Vrát'me sa k sporu, ktorý tematizoval E. Bernstein, ktorý komunistickým stranám vyčítal utopický radikalizmus, inšpirovaný blanquizmom. Odmietol Marxove teórie o pauperizácii pracujúcich a o nevyhnutnom zániku kapitalizmu, ako aj Stalinovu poučku o zostrovaní triedneho boja za socializmu (1928). Zlepšenie postavenia proletariátu nemožno dosiahnut' prostredníctvom revolúcie (konečný ciel'), ale presadzovaním sociálnych reforiem v rámci parlamentnej demokracie (hnutie). Bernstein mal pravdu, pokial' ide o flexibilitu kapitalizmu, aktuálne došlo k transformácii na globálny oligarchický systém, kedy hlavným zdrojom bohatstva je dobývanie renty. Na druhej strane finančná kríza (od roku 2008) predstavuje 
dôkaz, že Marxove poznatky o sebadeštrukčnej dynamike kapitalizmu sú z dlhodobého hladiska relevantné. Dočasný úspech západoeurópskych socialistov inšpiroval po roku 1989 politické elity aj l'udí v našej krajine; paradoxne vtedy, ked' už na Západe welfare state bol odpísaný. V tomto zmysle A. Dubček ako najvýraznejší politický predstavitel' „demokratického socializmu" zakotvil v SDSS, bol sedem mesiacov v roku 1992 jej predsedom; čiastočne prostredníctvom jeho charizmy strana získala členstvo v Socialistickej internacionále. Slovenská SD strana zanikla v roku 2004, českej SD strane hrozí zánik po októbrových vol'bách (2021). Podla posledného exilového predsedu ČSSD Karla Hrubého sa schyl'uje k funusu: „Sociální demokracie nemá nic nového, co veřejnosti nabídnout. Co by vrátilo člověku jistotu, zbavilo ho strachu z odcizené, zmanipulované politiky, ze spárů systémů a metafabrik, ze zajetí profitu, prosperity a nezřízeného konzumu. Stala se slibotechnou podobnou všem ostatním stranám, její ruce jsou zaměstnány hromaděním moci a profitu, ale voličům nepřinášejí nic nového“ (Hrubý 2021).

Bernstein nemal pravdu v tom, že ciel’ mu je ničím. Ak má sociálnodemokratický program oslovit' voličov, treba rozlišovat' dve roviny. Po prvé, v dlhodobej normatívnej rovine ciel'a otvorene diskutovat' o transformácii kapitalizmu, ktorý je ako systém trvale neudržatel'ný pre spôsob tvorby bohatstva (permanentný ekonomický rast). Po druhé, v strednedobej perspektíve iniciovat' prípadne podporovat' všetký opatrenia, ktoré vedú k transformácii a podporujú dekomodifikáciu, napríklad nepodmienený základný príjem, skrátenie pracovného času, dostupnost' verejných statkov, predovšetkým prístup ku vzdelaniu a zabezpečenie primeranej zdravotnej starostlivosti atd'. S tým súvisí v krátkodobom horizonte snaha o zlepšenie postavenia prekarizovaných aj prostredníctvom dielčích opatrení $\mathrm{v}$ parlamente, ako sú napríklad minimálna mzda, progresívne zdanenie, sociálne zabezpečenie a pod. Aktuálne sme svedkami, že sa nenaplnila premena proletariátu z triedy osebe na triedu pre seba, tieto kritéria ale spĺna vládnuca trieda, transnacionálna kapitalistická trieda. Dnes potrebujeme ideu socializmu, ktorá bude oponovat’ neoliberálnej globalizácii prostredníctvom nadnárodných korporácií.

Signifikantné však je, že sa začína celkom vážne uvažovat' o opatreniach, ktoré pred niekol'kými rokmi boli nemyslitel'né, ako sú Tobinova daň a nepodmienený príjem. Revidovaná idea socializmu musí vychádzat' z technologickej revolúcie 4.0, ktorá predpokladá relokalizáciu, takže by nahrávala predstave Parížskej komúny, menšie celky budú môct' fungovat' ekonomicky nezávisle. Takže treba premýšlat' o formách samosprávy namiesto historicky prekonanej teórie spoločenskej zmluvy, o nových formách participácie, nielen politickej, ale predovšetkým ekonomickej 
demokracie. A oprášit' Marxovu ideu o oslobodení jednotlivca od ekonomickej nevyhnutnosti, čomu by mohli napomôct' nové technológie a opustenie princípu neobmedzeného rastu v prospech optimalizácie typu nonrast (degrowth). ${ }^{17}$ Úvahy o transformácii kapitalizmu sa nemôžu vyhnút' novým výzvam, ktoré aktuálne popisuje vedecko-fantastická literatúra. Napríklad prechod k superinteligencii s rizikom formovania globálnej samovlády. ${ }^{18}$

\section{Literatúra}

ADORNO, T. W. (2019): Aspekty nového pravicového radikalizmu. Prednáška na Viedenskej univerzite v apríli 1967. Bratislava: Hadart Publishing.

ADORNO, T. W. (1973): Negative Dialectics. London: Routledge.

ADORNO, T. W. - HORKHEIMER, M. (2009): Dialektika osvícenství. Filosofické fragmenty. Praha: Oikoymenh.

ARENDT, H. (1965): Über die Revolution. München: Piper Verlag.

ARNASON, J. P. - BENYOVSZKY, L. - SKOVAJSA, M. (2010): Dějinnost, nadcivilizace a modernita. Praha, Togga.

BERNSTEIN, E. (1973): Die Voraussetzung des Sozialismus und die Aufgaben der Sozialdemokratie. Berlin: Dietz Verlag.

BENJAMIN, W. (1999): Iluminácie. Bratislava: Kalligram.

BOSTROM, N. (2018): Superinteligence. Až budou stroje chytřejší než lidé. Praha: Prostor.

CROZIER, M. - HUNTINGTON, S. P. - WATANUKI, J. (1975): The Crisis of Democracy. Report on the Governability of Democracy to the Trilateral Comission. New York: NY University Press.

DINUŠ, P. a kol. (2018): Október 1917 a súčasnost'. Bratislava: Veda.

FRASER, N. (2017): Progresivní neoliberalismus versus reakční populismus. In: Geiselberger, H. (ed): Velký regres. Mezinárodní rozprava o duchovní situaci dneška. Praha: Rybka publishers, 52 - 56.

GOLDBERG, J. (2009): Liberal Fascism. The Secret History of the Left from Mussolini to the Politics of Meaning. London: Penguin Books.

GRAMCSI, A. (1988): Spoločnost', politika, filozofia. Bratislava: Pravda.

HERMANN, T. (2014): Karel Hrubý - jsou jisté hodnoty, které nemůžete vzdát. In: Homines scientiarum I. Pardubice: Vydavatelství Univerzity P.

HOHOŠ, L. (2018): „Civilizácia na rázcestí“ po polstoročí. Bratislava: Veda.

HONNETH, A. (2020): Idea socializmu. Pokus o aktualizáciu. Bratislava: Veda.

HROCH, M. (2016): Hledání souvislostí. Eseje z komparativních dějin Evropy. Praha: Sociologické nakladatelství.

HRUBÝ, K. (2018): Cesty komunistickou diktaturou. Kritické studie a eseje. Praha: Argo.

\footnotetext{
17 Pozri (Hohoš 2018).

18 Pozri (Bostrom 2018, 269-280).
} 
HRUBÝ, K. (2021): Pohřební nálada. Web. 2021. <https://denikreferendum.cz/ clanek/32158-pohrebni-nalada>.

KRAPFL., J. (2019): Revolúcia s l'udskou tvárou. Politika, kultúra a spoločenstvo v Československu po 17.novembri 1989. Bratislava: Kalligram.

MARX, K. - ENGELS, F. (1977): Vybrané spisy v piatich zväzkoch. Bratislava: Pravda. MASARYK, T. G. (1928): Světová revoluce za války a ve válce. Praha: Orbis.

MOLČANOV, N. N. (1989): Auguste Blanqui. Bratislava: Pravda.

PATOČKA, J. (1996): Péče o duši I. Praha: Oikoymenh.

PATOČKA, J. (2007): „Ideologie a život v ideji“. Citované podl’a J.Novotný: Filozofova tichá válka. In: Listy, (4).

PATOČKA, J. (2020): Living in Problemacity. Praha: Oikoymenh.

RAWLS, J. (2009): Právo národů. Praha: Filosofia.

REICH, R. (2008): Supercapitalism. The Battle for Democracy in an Age of Big Business. Cambridge: Icon Books.

ROBINSON, W. (2019): Global Capitalist Crisis and Twenty-First Century Fascism: Beyond the Trump Hype. In: Science \& Society, 83 (2).

ŠTROUGAL, L. (2009): Paměti a úvahy. Praha: Epocha.

doc. PhDr. Ladislav Hohoš, CSc.

Víglašská 9

85107 Bratislava

ladislav.hohos@gmail.com 